\title{
Lack of Association between Interleukin-18 -607 C/A Gene Polymorphism and Pulmonary Tuberculosis in Zahedan, Southeast Iran
}

\author{
Taheri M. ${ }^{1,2}$, Hashemi-Shahri S. M. ${ }^{3}$, Hamzehnejadi M. $^{3}$, \\ Naderi M. ${ }^{3}$, Moazeni-Roodi A. ${ }^{3}$, Bahari G. ${ }^{4}$, Hashemi M. ${ }^{1,4}$ \\ ${ }^{1}$ Cellular and Molecular Research Center, Zahedan University of Medical Sciences, \\ Zahedan, Iran; \\ ${ }^{2}$ Department of Genetics, School of Medicine, Zahedan University of Medical \\ Sciences, Zahedan, Iran; \\ ${ }^{3}$ Research Center for Infectious Diseases and Tropical Medicine, Zahedan \\ University of Medical Sciences, Zahedan, Iran; \\ ${ }^{4}$ Department of Clinical Biochemistry, School of Medicine, Zahedan University \\ of Medical Sciences, Zahedan, Iran
}

Received June 30, 2011; Accepted January 16, 2012.

Key words: Tuberculosis - IL-18 - Single nucleotide polymorphism

\begin{abstract}
Interleukin-18 (IL-18) plays a critical role in immune response, contributing to the pathogenesis and pathophysiology of infectious diseases.

Polymorphisms in the IL-18 genes are known to influence expression levels and may be associated with outcome of infections. The objective of this study was to determine whether the presence of IL-18 polymorphisms -607 A/C (rs1946518) was associated with tuberculosis disease. We investigated the functional polymorphism of IL-18 (rs1946518) in 174 patients with pulmonary tuberculosis (PTB) and 177 healthy subjects. Genotype analysis was done using tetra amplification refractory mutation system-PCR (T-ARMS-PCR). The allelic and genotypic frequencies of the IL-18 polymorphism did not differ significantly between PTB and the controls. Our finding suggests that IL-18 polymorphism (rs1946518) may not be a risk factor for susceptibility to tuberculosis in a sample of Iranian population. Further studies are required to validate our findings.
\end{abstract}

This study was supported by dissertation grant from Zahedan School of Medicine.

Mailing Address: Prof. Mohammad Hashemi, PhD., Department of Clinical Biochemistry, School of Medicine, Zahedan University of Medical Sciences, Zahedan, Iran; e-mails: mhd.hashemi@gmail.com, hashemim@zaums.ac.ir

(c) Charles University in Prague - Karolinum Press, Prague 2012 


\section{Introduction}

Tuberculosis (TB), caused by Mycobacterium tuberculosis, is a major cause of morbidity and mortality throughout the world especially in Asia and Africa and remains a public health problem. It can affect almost all of the body, including the brain, the kidneys and the bones, but predominately manifests itself in the lungs where it is called pulmonary tuberculosis.

One third of the earth's population is infected with TB but only $10 \%$ individuals infected will develop the disease and about 2 million people die due to the disease each year. Increasing evidence indicates that host genetic factors play an important role in susceptibility to TB (Stein, 2011).

IL-18 is a proinflammatory cytokine produced mainly by macrophages and monocyte but also by dendritic cells, Kupffer cells, keratinocytes, synovial, fibroblasts, epithelial cells, and osteoblasts cells and plays a crucial role in regulation of both innate and acquired immunity and have an important role in inflammatory and infectious diseases (Schneider et al., 2010).

IL-18, in synergy with IL-12 or IL-21 enhances IFN- $\gamma$ production in human NK and T Cells (Shigehara et al., 2001; Strengell et al., 2003). The IL-18 gene is located on chromosome 11(11q22.2-22.3), and contains many polymorphism, especially in the promoter region (Smith and Humphries, 2009). There are two polymorphisms $(-137 \mathrm{G} / \mathrm{C}$ and $-607 \mathrm{~A} / \mathrm{C})$ in promoter seems to affect the expression level of IL-18 at transcription level (Giedraitis et al., 2001). To the best of our knowledge, there are only two reports regarding the association of IL-18 gene polymorphisms and pulmonary tuberculosis (Harishankar et al., 2007; Han et al., 2011). The present study aimed to determine the possible association between IL-18 -607 C/A gene polymorphism and pulmonary tuberculosis in a sample of Iranian population.

\section{Material and Methods}

This case-control study was performed on 174 patients with pulmonary tuberculosis (110 women and 64 men; ages $50.17 \pm 20.47$ ) and 177 healthy subjects (97 women and 80 men; ages $46.88 \pm 15.45)$. There was no significant difference among the groups regarding sex and age $(p>0.05)$. The diagnosis of PTB was based on clinical, radiological, sputum Acid Fast Bacillus (AFB) smear positivity, culture and response to antituberculosis chemotherapy as described previously (Naderi et al., 2009, 2010).

The project was approved by the local Ethics Committee of the Zahedan University of Medical Sciences, and written informed consent was taken from all participants. Blood samples were collected in Na-EDTA tubes from patients and healthy controls and stored at $-20^{\circ} \mathrm{C}$ until DNA extraction.

Genomic DNA extraction from blood samples was carried out as described previously (Hashemi et al., 2010a). Tetra primer ARMS-PCR is a simple and rapid method for detection of single nucleotide polymorphism (SNP) (Ye et al., 2001; Hashemi et al., 2010b, 2011a; Naderi et al., 2011). We designed tetra-ARMS-PCR 
for detection of $-607 \mathrm{C} / \mathrm{A}$ polymorphism of II-18 gene. We used two external primers (forward outer and reverse outer) and two inner primers (forward inner and reverse inner) that are shown in Table 1.

Product sizes were; 208 bp for $C$ allele and 278 bp for A allele, while the product size of the two outer primers (control band) was $440 \mathrm{bp}$ as is shown schematically in Figure 1.

Polymerase chain reaction (PCR) was performed using commercially available PCR premix (AccuPower PCR PreMix, BIONEER, Daejeon, South Korea) according to the manufacturer recommended protocol. Into a 0.2-ml PCR tube containing the AccuPower PCR Pre-Mix, $1 \mu$ template DNA ( 100 ng/ $\mu$ l), $1 \mu$ of each primer $(10 \mu \mathrm{M})$ and $15 \mu \mathrm{l}$ DNase-free water were added. The total volume for the PCR was $20 \mu \mathrm{l}$.

The PCR protocol for detection of $-607 \mathrm{C} / \mathrm{A}$ polymorphism of IL-18 was as follows: initial denaturation at $95^{\circ} \mathrm{C}$ for 5 min followed by 30 cycles, consisting of denaturation at $95{ }^{\circ} \mathrm{C}$ for $30 \mathrm{~s}$, annealing at $54^{\circ} \mathrm{C}$ for $20 \mathrm{~s}$, and extension at $72{ }^{\circ} \mathrm{C}$ for $30 \mathrm{~s}$. Final extension was performed at $72{ }^{\circ} \mathrm{C}$ for $10 \mathrm{~min}$. The PCR products were analyzed by electrophoresis on a $2 \%$ agarose gel containing $0.5 \mu \mathrm{g} / \mathrm{ml}$ ethidium bromide and visualized by transillumination with UV light and photograph was taken (Figure 2). We regenotyped approximately $10 \%$ of the samples to verify the initial results. The check confirmed the previous genotyping results by $100 \%$.

The statistical analysis of the data was performed using the SPSS 18.0 software. Demographics and biochemical parameters between the groups were analyses

\section{Table 1 - Primers used for polymorphism determination}

\begin{tabular}{llc}
\hline Primer & Sequence $\left(5^{\prime} \rightarrow 3^{\prime}\right)$ & $T_{\mathrm{m}}\left({ }^{\circ} \mathrm{C}\right)$ \\
\hline Forward outer primer & CCTACAATGTTACAACACTTAAAAT & 50 \\
Reverse outer primer & ATAAGCCCTAAATATATGTATCCTTA & 49 \\
Forward inner primer & GATACCATCATTAGAATTTTGTG & 48 \\
Reverse inner primer & GCAGAAAGTGTAAAAATTATCAA & 48 \\
\hline
\end{tabular}

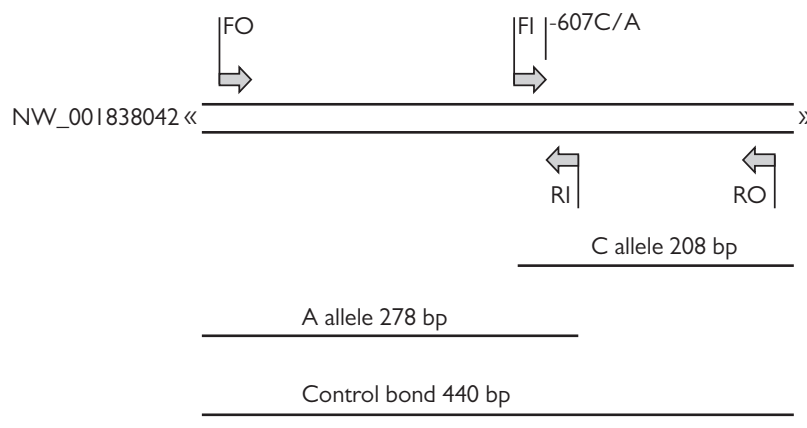

Figure 1 - Schematic illustration of tetra amplification refractory mutation system-polymerase chain reaction (tetra-ARMS-PCR) assay for detection of IL-18-607 C/A polymorphism. Two forward and two reverse specific primers are used to produce three potential products. Product sizes were: 208 bp for C allele, 278 bp for $A$ allele and 440 bp for two outer primers (control band).

Taheri M. et al. 


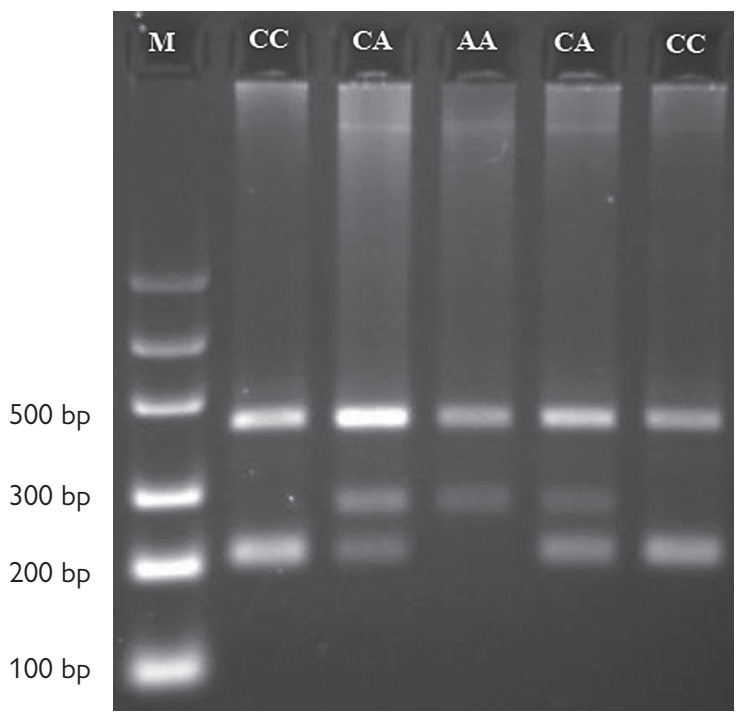

Figure 2 - Electrophoresis pattern of tetra amplification refractory mutation system-polymerase chain reaction (tetra-ARMS-PCR) for detection of IL-18-607 C/A polymorphism.

by independent sample $t$-test for continuous data and $\chi^{2}$ test for categorical data. The associations between genotypes of IL-18 gene and PTB were estimated by computing the odds ratio $(\mathrm{OR})$ and $95 \%$ confidence intervals $(95 \% \mathrm{Cl})$ from logistic regression analyses.

\section{Results}

The allele and genotype frequencies in patient and control groups were summarized in Table 2. The wild-type genotype (CC) was observed in 74 (42.5\%) of the patients; whereas 80 (46.0\%) were heterozygous (CA) and 20 (11.5\%) were homozygous (AA). In the control group, the frequencies of genotypes were 68 (38.5\%) for CC, $90(50.8 \%)$ for CA and 19 (10.7\%) for AA. There were no significant differences regarding $-607 \mathrm{C} / \mathrm{A}$ polymorphism of IL-18 among PTB patients and normal

Table 2 - The genotypes and allele distribution of IL-18 polymorphism in case and control groups

\begin{tabular}{|c|c|c|c|c|c|c|}
\hline Polymorphism & $\begin{array}{l}\text { РТB } \\
\text { n (\%) }\end{array}$ & $\begin{array}{c}\text { Normal } \\
\text { n (\%) }\end{array}$ & $\begin{array}{c}\text { OR } \\
(95 \% \mathrm{Cl})\end{array}$ & $P$ & $\begin{array}{c}* \mathrm{OR} \\
(95 \% \mathrm{Cl})\end{array}$ & $P$ \\
\hline \multicolumn{7}{|c|}{ Genotypes } \\
\hline$\overline{C C}$ & $74(42.5)$ & $68(38.5)$ & 1.00 & & 1.00 & \\
\hline CA & $80(46.0)$ & $90(50.8)$ & $0.82(0.52-1.28)$ & 0.374 & $0.79(0.50-1.24)$ & 0.307 \\
\hline $\mathrm{AA}$ & $20(11.5)$ & $19(10.7)$ & $0.97(0.48-1.97)$ & 0.927 & $1.00(0.49-2.04)$ & 0.995 \\
\hline \multicolumn{7}{|c|}{ Alleles } \\
\hline $\bar{C}$ & $228(65.5)$ & $226(63.8)$ & & & & \\
\hline$A$ & $120(34.5)$ & $128(36.2)$ & $0.93(0.68-1.27)$ & 0.693 & & \\
\hline
\end{tabular}

*adjusted for age and sex 
subjects $(p=0.656)$. No significant differences were observed among PTB and control subjects regarding allele frequencies (0.693).

The IL-18 -607 C/A genotypes polymorphism in case and control groups was consistent with Hardy-Weinberg equilibrium.

\section{Discussion}

Tuberculosis kills more people each year than any other single infectious disease. Development of tuberculosis disease depends on interaction between the pathogen, environment, and the host. Many studies support that the differences in host immune genes is accompanying with susceptibility/resistance to TB (Sharma et al., 2010; Hashemi et al., 2011b).

IL-18 which is an important interferon- $\gamma$ (IFN- $\gamma$ ) inducer can activate immune cells, promoting the activation and proliferation of $T$ and natural killer cells and the antituberculosis response (Sugawara, 2000). IL-18 is involved in protective immunity against a broad range of intracellular pathogens. It has been reported that mice lacking IL-18 were highly susceptible to $M$. tuberculosis infection and succumbed more rapidly than WT B6 mice (Schneider et al., 2010).

It is being thought that two SNPs in the promoter region of the IL-18 gene regulate the expression of gene at the transcriptional level and changed the production level of IL-18 (Giedraitis et al., 2001). Indeed variation at -607 C/A of IL-18 gene disrupts cAMP-responsive element-binding protein binding site, influence the quantity of transcribed IL-18 mRNA (Giedraitis et al., 2001). Khripko et al. (2008) demonstrated that subjects carrying allele $-607 \mathrm{~A}$ have significant increase in IL-18 production compared to wild type in Southwestern Siberia. IL-18, in synergy with IL-12 or IL-21 enhances IFN- $\gamma$ production in human NK and T Cells (Shigehara et al., 2001; Strengell et al., 2003). In our previous study, we showed that IFN- $\gamma+874$ T/A polymorphism confers susceptibility to pulmonary tuberculosis in a sample of Iranian population (Hashemi et al., 2011b). In the present study, we attempted to determine the impact of IL-18 -607 C/A polymorphism on the susceptibility of PTB in our population. We found no association between IL-18 -607 C/A polymorphism and susceptibility to PTB. Our results are in agreement with the findings of Harishankar et al. (2007). They found that the IL-18 gene promoter polymorphisms are not associated with susceptibility or resistance to pulmonary tuberculosis in south Indian population. Contrary to our findings, Han et al. (2011) demonstrated an association between IL-18 polymorphisms and susceptibility to PTB and increase risk of developing the disease in Chinese Han population. The controversy results suggesting that the impact of IL-18 -607 C/A gene polymorphism on PTB is likely to be influenced by ethnic origin.

Many studies demonstrated productivity role of IL-18 in Mycobacterium tuberculosis infections (Vankayalapati et al., 2000; Akgun et al., 2005; Schneider et al., 2010).

In conclusion, we suggest that IL-18 $-607 \mathrm{C} / \mathrm{A}$ gene promoter polymorphism may not be a major genetic factor for susceptibility to pulmonary tuberculosis in a sample 
of Iranian population. Larger studies with different ethnicity are required to validate our findings.

Acknowledgements: The authors thanks to the patients and healthy subjects who willingly participated in the study.

\section{References}

Akgun, M., Saglam, L., Kaynar, H., Yildirim, A. K., Mirici, A., Gorguner, M., Meral, M., Ozden, K. (2005) Serum IL-18 levels in tuberculosis: comparison with pneumonia, lung cancer and healthy controls. Respirology 10, 295-299.

Giedraitis, V., He, B., Huang, W. X., Hillert, J. (2001) Cloning and mutation analysis of the human IL-18 promoter: a possible role of polymorphisms in expression regulation. J. Neuroimmunol. 112, 146-152.

Han, M., Yue, J., Lian, Y. Y., Zhao, Y. L., Wang, H. X., Liu, L. R. (2011) Relationship between single nucleotide polymorphism of interleukin-18 and susceptibility to pulmonary tuberculosis in the Chinese Han population. Microbiol. Immunol. 55, 388-393.

Harishankar, M., Selvaraj, P., Rajeswari, D. N., Anand, S. P., Narayanan, P. R. (2007) Promoter polymorphism of IL-18 gene in pulmonary tuberculosis in South Indian population. Int. J. Immunogenet. 34, 317-320.

Hashemi, M., Moazeni-Roodi, A. K., Fazaeli, A., Sandoughi, M., Bardestani, G. R., Kordi-Tamandani, D. M., Ghavami, S. (2010a) Lack of association between paraoxonase-1 Q192R polymorphism and rheumatoid arthritis in southeast Iran. Genet. Mol. Res. 9, 333-339.

Hashemi, M., Moazeni-Roodi, A. K., Fazaeli, A., Sandoughi, M., Taheri, M., Bardestani, G. R., Zakeri, Z., KordiTamandani, D. M., Ghavami, S. (2010b) The L55M polymorphism of paraoxonase-1 is a risk factor for rheumatoid arthritis. Genet. Mol. Res. 9, 1735-1741.

Hashemi, M., Hoseini, H., Yaghmaei, P., Moazeni-Roodi, A., Bahari, A., Hashemzehi, N., Shafieipour, S. (2011a) Association of polymorphisms in glutamate-cysteine ligase catalytic subunit and microsomal triglyceride transfer protein genes with nonalcoholic fatty liver disease. DNA Cell Biol. DOI: 10.1089/dna.2010.1162.

Hashemi, M., Sharifi-Mood, B., Nezamdoost, M., Moazeni-Roodi, A., Naderi, M., Kouhpayeh, H., Taheri, M., Ghavami, S. (2011b) Functional polymorphism of interferon- $\gamma$ (IFN- $\gamma$ ) gene +874 T/A polymorphism is associated with pulmonary tuberculosis in Zahedan, southeast Iran. Prague Med. Rep. 112, 38-43.

Khripko, O. P., Sennikova, N. S., Lopatnikova, J. A., Khripko, J. I., Filipenko, M. L., Khrapov, E. A., Gelfgat, E. L., Yakushenko, E. V., Kozlov, V. A., Sennikov, S. V. (2008) Association of single nucleotide polymorphisms in the IL-18 gene with production of IL-18 protein by mononuclear cells from healthy donors. Mediators Inflamm. 2008, 309721.

Naderi, M., Hashemi, M., Kouhpayeh, H., Ahmadi, R. (2009) The status of serum procalcitonin in pulmonary tuberculosis and nontuberculosis pulmonary disease. J. Pak. Med. Assoc. 59, 647-648.

Naderi, M., Hashemi, M., Mehdizadeh, A., Mehrabifar, H., Kouhpayeh, H. R., Ansari, H., Bahari, G. R., Ghavami, S. (2010) Serum adenosine deaminase activity and total antioxidant capacity of plasma in pulmonary tuberculosis and non-tuberculosis pulmonary disease. Turk. J. Med. Sci. 40, 701-706.

Naderi, M., Hashemi, M., Karami, H., Moazeni-Roodi, A., Sharifi-Mood, B., Kouhpayeh, H., Taheri,

M., Ghavami, S. (2011) Lack of association between rs1024611 (-2581 A/G) polymorphism in CC-chemokine ligand 2 and susceptibility to pulmonary tuberculosis in Zahedan, southeast Iran. Prague Med. Rep. 112, 272-278.

Schneider, B. E., Korbel, D., Hagens, K., Koch, M., Raupach, B., Enders, J., Kaufmann, S. H., Mittrucker, H. W., Schaible, U. E. (2010) A role for IL-18 in protective immunity against Mycobacterium tuberculosis. Eur. J. Immunol. 40, 396-405.

The -607 C/A Polymorphism of IL- 18 Gene in Pulmonary Tuberculosis 
Sharma, S., Kumar, V., Khosla, R., Kajal, N., Sarin, B., Sehajpal, P. (2010) Association of P2X7 receptor +1513 (A-->C) polymorphism with tuberculosis in a Punjabi population. Int. J. Tuberc. Lung Dis. 14, 1159-1163.

Shigehara, K., Shijubo, N., Ohmichi, M., Takahashi, R., Kon, S., Okamura, H., Kurimoto, M., Hiraga, Y.,

Tatsuno, T., Abe, S., Sato, N. (2001) IL-12 and IL-18 are increased and stimulate IFN-gamma production in sarcoid lungs. J. Immunol. 166, 642-649.

Smith, A. J., Humphries, S. E. (2009) Cytokine and cytokine receptor gene polymorphisms and their functionality. Cytokine Growth Factor Rev. 20, 43-59.

Stein, C. M. (2011) Genetic epidemiology of tuberculosis susceptibility: impact of study design. PLoS Pathog. 7, e1001189.

Strengell, M., Matikainen, S., Siren, J., Lehtonen, A., Foster, D., Julkunen, I., Sareneva, T. (2003) IL-21 in synergy with IL-15 or IL-18 enhances IFN-gamma production in human NK and T cells. J. Immunol. 170, 5464-5469.

Sugawara, I. (2000) Interleukin-18 (IL-18) and infectious diseases, with special emphasis on diseases induced by intracellular pathogens. Microbes Infect. 2, 1257-1263.

Vankayalapati, R., Wizel, B., Weis, S. E., Samten, B., Girard, W. M., Barnes, P. F. (2000) Production of interleukin-18 in human tuberculosis. J. Infect. Dis. 182, 234-239.

Ye, S., Dhillon, S., Ke, X., Collins, A. R., Day, I. N. (2001) An efficient procedure for genotyping single nucleotide polymorphisms. Nucleic Acids Res. 29, e88.

Taheri M. et al. 